\title{
The Sensitivity of Residential Electricity Demand in Indonesia
}

\author{
Stranti Nastiti Kusumaningrum
}

\begin{abstract}
Since 2013, the residential electricity price for High VA (Volt-Ampere) households has changed due to changes in pricing policies. This paper analyzes the responsiveness of residential electricity demand to the change in electricity prices and income among two different household groups (Low VA and High VA) in 2011 and 2014. Using an electricity consumption model and the Quantile Regression method, the results show that residential electricity demand is price and income inelastic. Income elasticity is lower than price elasticity. Furthermore, the effects on price elasticity also found in the Low VA group, whose rate remained stable. At the same time, evidence proves the impact of the change in pricing policy on income elasticity remains unclear. This result implies that the government has to be more careful in regulating electricity prices for the low VA group while maintaining economic stability.
\end{abstract}

Keywords: sensitivity, electricity, quantile regression

\begin{abstract}
Abstrak
Tarif listrik pada sektor rumah tangga dengan daya sambungan menengah ke atas (High VA) mulai berubah semenjak tahun 2013. Tulisan ini menganalisa responsivitas dari permintaan listrik rumah tangga terhadap perubahan harga dan pendapatan pada dua kelompok rumah tangga (Low VA dan High VA) di tahun 2011 dan 2014. Dengan menggunakan model konsumsi listrik dan metode regresi kuantil, didapatkan hasil yang menunjukkan bahwa permintaan listrik rumah tangga bersifat inelastic terhadap harga dan pendapatan. Elastisitas pendapatan lebih rendah daripada elastisitas harga. Lebih lanjut diketahui bahwa pengaruh terhadap elastisitas pendapatan juga dapat dilihat di kelompok Low $V A$, walaupun kelompok ini tidak mengalami perubahan harga. Sementara itu, hasil penelitian tidak berhasil menyimpulkan dampak perubahan kebijakan tariff terhadap elastisitas pendapatan. Keseluruhan hasil penelitian ini dapat menjadi pertimbangan pemerintah untuk lebih berhati-hati dalam menyusun kebijakan harga listrik untuk kelompok Low VA sembari mempertahankan kestabilan ekonomi.
\end{abstract}

Kata Kunci: sensitivitas, listrik, regresi kuantil

\section{How to Cite:}

Kusumaningrum, S. N. (2018). The Sensitivity of Residential Electricity Demand in Indonesia. Signifikan: Jurnal IImu Ekonomi. Vol. 7 (2): 247 - 266. doi: http//dx.doi.org/10.15408/sjie.v7i2.6048. 


\section{Introduction}

The decision regarding how much electricity should consume in each period is different for every household due to a variety of reasons. Electricity is consumed to fulfill a variety of needs with a broad range of importance, from necessities to recreational and luxury means. The total consumption is determined by various factors, such as electricity price and income level (Huang, 2014; Longhi, 2015; Romero-Jordan et al., 2016). The diversity of dwelling attributes, age and region may also result in differences in electricity consumptions (Huang, 2014; Yamasaki and Tominaga, 1997).

Analyzing household electricity consumption in Indonesia is important. One of the reasons is that in the residential sector the consumption has been increasing over the years and comprises the largest proportion compared to other sectors with $43.72 \%$ share of all electricity consumption in 2015, with 88\% electrification ratio (the Republic of Indonesia, Ministry of Energy and Mineral Resources (MEMR), 2016). Another reason is the change in electricity pricing regulation. It is important to know the effects of such development on the household sector gave the responsibility of the Government of Indonesia (GOI) to control strategic sectors and use all natural resources for the prosperity of citizens, as cited in the 1945 Constitution of the Republic of Indonesia.

The residential electricity tariff system in Indonesia is complex. The tariff is divided into six groups based on the maximum power installed in the consumers' house, with the lowest being 450 Volt-Ampere (VA) and the highest being 6,600 VA and above, and each group has different pricing schedules (based on Presidential Decree No. 8/2011 and Ministerial Decree of Energy and Mineral Resources of Indonesia No. 30/2013, 09/2014, \& 19/2014). The $450 \mathrm{VA}$ and $900 \mathrm{VA}$ consumer groups have the lowest basic and utilization charges partly due to government's subsidy. Such groups also have a flat pricing tariff based on the electricity usage, whereas the others have a progressive tariff if they are not using the prepaid system. In this system, the consumers buy a token card to pay for the limited units of electrical power that can automatically cut off when the usage reaches the limit. Using the prepaid system, the electricity tariff is based on the electricity usage.

Nevertheless, the maximum power installation may not reflect each household's consumption. Consumers with 900 VA may consume electricity in the same amount as consumers in 1,300 VA; there is no maximum amount that can be consumed in a period. However, the maximum power installation limits the amount of electricity that can be used simultaneously. Therefore, when all types of households consume the maximum amount, there will be no chance for households in 900 VA to consume more than households in $1,300 \mathrm{VA}$.

During 2013 and 2014, the government raised electricity prices for industrial sectors and upper-class households (households with 1,300 VA power installed) to provide price security to power plant investors and to reduce electricity subsidies simultaneously. The government has planned to build many new power plants that will produce an additional 35,000 megawatts (MW) of power by 2019, hoping that it will increase the electrification ratio. Such goal has to be supported by power providers, which are Perusahaan Listrik 
Negara (PLN) as a state-owned electricity company and/or private investors. However, the government is the one who sets the selling price and gives annual subsidy to cover the difference between cost and revenue of power plants with the approval of Indonesian Parliament (Damuri, 2013). As PLN could not set the end price, it reported a loss for years (Damuri, 2013). On the other hand, subsidy in price has pressurized national budget for years deterring efforts to achieve energy efficiency (International Energy Agency [IEA], 2015).

Historically, the government has planned to gradually remove the electricity subsidy and raise the electricity tariffs since 2013 (MEMR, 2016). In 2013, first, the consumers with the most significant maximum (6,600 VA) experienced a gradual tariff increase before the tariff system changed to tariff adjustment in 2014. This system allowed prices to be adjusted monthly depending on fuel prices, exchange rates, and monthly inflation (PLN, 2014) that may cause price fluctuations. Since October in the same year, electricity prices for consumers between 1,300 VA to 5,500 VA had increased gradually until the end of 2014 when the electricity tariff (Rp/kWh) of the said groups was equal to the 6,600 VA. The $450 \mathrm{VA}$ and 900 VA electricity prices did not change during these years. Also, since early 2017, the pricing structure for households with 900 VA has also started to change. The government began to revoke the subsidy for consumers in $900 \mathrm{VA}$, although not entirely through a program called Subsidi Listrik Tepat Sasaran (SLTS) or the Accurate Electricity Tariff Subsidy (MEMR, 2017). Such regulation induces a rise in price among the 900 VA consumers who are not considered low-income consumers as the government only targets electricity subsidy to be given to the real low-income citizens.

Some studies are touching on the subject of household electricity demand. The previous studies derived the demand for household electricity from household production and consumer behavior theories. However, the electricity demand function derived from household production function rarely used due to unavailability of goods' price data in the analysis (Narayan and Smyth, 2005; Pourazarm and Cooray, 2013). Under the household production theory, in the markets, households buy electricity or gas as a good to be an input in producing an electric composite commodity together with capital stock equipment; so that the electricity or gas will indirectly impact the utility of households through the commodity (Alberini and Filippini, 2011; Pourazarm and Cooray, 2013). In the household production theory, electricity demand function derived from maximizing utility function subject to a budget constraint (Alberini and Filippini, 2011). Meanwhile, based on consumer behavior theory, electricity is considered to affect consumer utility directly (Pourazarm and Cooray, 2013).

The studies on the impact of price on electricity consumption for every income level found different results. In Norway, high-income households are more sensitive to price than low-income households while, in the U.S., the price elasticity of household electricity consumption decreases concerning a rise in income (Alberini et al., 2011; Nesbakken, 1999). On the other hand, an analysis in Spain regarding electricity consumption revealed the U-shape price elasticity on quantile demand, meaning that the group of consumers who consume the least and the highest are less responsive to change in prices than the middle consumer group (Romero-Jordan et al., 2016). Meanwhile, 
in the U.S. a study found that as electricity consumption rises, price elasticity decreases (Reiss and White, 2005).

The elasticity of income to electricity demand can also be different concerning income levels. An increase in income will increase the electricity demand in low-income levels to fulfill their basic needs and additional needs to live more comfortably (Romero-Jordan, et al., 2016). However, at one point of income level, the increases in income have little impact on the consumption (Romero-Jordan et al., 2016). Additionally, a study on the income elasticity of electricity demand in 11 OECD countries states that electricity demand responds weakly to income (Krishnamurthy and Kriström, 2015).

In the case of Indonesia, a few earlier studies can be noted. A finding based on 600 respondents' primary survey in seven cities in Java and Sumatra Islands found that higher the ratio of electrical energy expenditure to income, the more vulnerable a price shock the household group is exposed to (Batih and Sorapipatana, 2016). Additionally, a relatively more high electricity price is likely to pressurize consumers to conserve more electrical energy (Batih and Sorapipatana, 2016). Meanwhile, another previous research about Indonesia using Computational General Equilibrium method and Indonesia Family Life Survey (IFLS) 2007 data found that the budget share of electricity uniformly decreases with income (Durand-lasserve et al., 2015). However, such paper using National Socio-Economic Survey (SUSENAS) data still rarely can be found. Compared to IFLS dataset, SUSENAS has a different structure. Therefore, this research tries to reinvestigate the issue using SUSENAS data to complete the view.

This paper aims to identify how the change in electricity price affects the responsiveness of electricity consumption to price and consumer income in different quantiles of consumption levels in Indonesia using two sets of cross-section data from the SUSENAS in years 2011 and 2014. By applying Quantile Regression methods to the SUSENAS data, this research intends to give more insight into the impact of the new electricity pricing policy that has been implemented in 2013. Subsequently, the effect of the newer pricing schedule for 900 VA households in 2017 may be predicted.

\section{Method}

Electricity demand depends on electricity price, income, and other socio-economic factors of consumers (Alberini and Filippini, 2011) that can write as follows:

$$
E=E(P, Y ; Z)
$$

Where: $\mathrm{E}$ is electricity consumption; $\mathrm{P}$ is price of electricity; $\mathrm{Y}$ is the household's income; and $\mathrm{Z}$ represents household characteristics influencing electricity consumption.

Households' characteristics used in this study follow the work of Romero-Jordan et al. (2016) and Radforst et al. (2012); they are number of appliances owned, educational level of the breadwinner in the house and the region where the household lives. This study uses dummy javabali and urban to represent the living region. Taking the natural logarithm transformation of electricity demand, the equation becomes: 


$$
\begin{aligned}
& \ln E_{i t}=\beta_{1_{i t}}+\beta_{2_{i t}} \ln P_{i t}+\beta_{3_{i t}} \ln Y_{i t}+\beta_{4_{i t}} E d u_{1_{i t}}+\beta_{5_{i t}} E d u_{2_{i t}}+ \\
& \beta_{6_{i}} E d u_{3_{i t}}+\beta_{7_{i}} E d u_{4_{i}}+\beta_{8_{i t}} \text { equipment }_{i t}+\beta_{9_{i t}} \text { javabali }_{i t}+ \\
& \beta_{10_{i t}} \text { urban }_{i t}+e_{i t}
\end{aligned}
$$

Where: E is Electricity Consumption (kWh); P is Electricity Price (Rupiah/kWh); Y is Income (IDR); Edu 1 is Dummy variable, 1 if the years of education of the head of the family are 6, 0 if otherwise; Edu2 is Dummy variable, 1 if the years of education of the head of the family are 9, 0 if otherwise; Edu3 is Dummy variable, 1 if the years of education of the head of the family are 12, 0 if otherwise; Edu4 is Dummy variable, 1 if the years of education of the head of the family are more than 12, 0 if otherwise; equipment = Dummy variable, 1 if the household has either Air Conditioner, refrigerator, or water heater, 0 if otherwise; javabali = Dummy variable, 1 if the household located in Java or Bali Islands, 0 if otherwise; urban = Dummy variable, 1 if the household is in urban area, 0 if otherwise; $i$ is household in respective group; and $\mathrm{t}$ is year of observation; 2011 and 2014.

The model is estimated using Quantile Regression (QR) to look at the responses of electricity consumption due to changes in all independent variables in every quantile of consumption. The regression is estimated for the years 2011 and 2014 for 2 groups of households based on the maximum power installed in the house: (1) Low VA (450-900 VA) and (2) High VA (1,300 VA and above). These two groups are chosen because price changes due to regulations since 2013 only apply to consumers that have at least 1,300 VA maximum powers installed in their houses.

$\mathrm{QR}$ is used due to some reasons. First, $\mathrm{QR}$ is more beneficial than Ordinary Least Square (OLS) to estimate this study's purposes. QR regresses the sample data in each quantile of conditional distribution of the dependent variable, while OLS regresses the average of the data set (Hagfors, et al, 2016; Romero-Jordan, et al., 2016). OLS undeniably can also estimate each percentile of data set, but the problem of adverse selection may occur (RomeroJordan, et al., 2016). Therefore, QR can give wider perspective than OLS. Another advantage is that $\mathrm{QR}$ can also reduce the problem of outliers in the data set (Romero-Jordan et al., 2016). The model for $Q R$ becomes:

$$
\begin{aligned}
& \ln E_{i t}=\beta_{1_{i t}}+\beta_{2 \theta_{i t}} \ln P_{i t}+\beta_{3 \theta_{i t}} \ln Y_{i t}+\beta_{4 \theta_{i t}} E d u_{1_{i t}}+\beta_{5 \theta_{i t}} E d u_{2 i t}+ \\
& \beta_{6 \theta_{i t}} E d u_{3 i}+\beta_{7 \theta_{i t}} E d u_{4 i t}+\beta_{8 \theta_{i t}} \text { equipment }_{i t}+\beta_{9 \theta_{i t}} \text { javabali }_{i t}+ \\
& \beta_{10 \theta_{i t}} \text { urban }_{i t}+\ln \varepsilon_{\theta i t}
\end{aligned}
$$

For $0<\theta<1$, with Quantile $_{\theta}\left(\frac{y}{x}\right)=x_{i} \beta_{\theta}$ where $y$ is the dependent variable and $x$ is the set of covariates, with quantile $\theta$ being conditional distribution in the $\theta$ quantiles. The $\beta_{\theta j}$ parameters can be interpreted as the impact of the respective variable on the demand for electricity in quantile $\theta$.

The variables used in this paper are a household level data taken from National SocioEconomic Survey (SUSENAS) conducted by National Bureau of Statistics, Indonesia for the years 2011 and 2014. These two years are chosen to capture the different pattern of electricity consumption between quantiles due to change in price. The variables of electricity consumption and income are taken as they are from the survey data. The unit price of 
electricity variable is calculated by dividing the electricity expenditure by the number of electricity consumption in each household.

Before beginning the estimation processes, the dataset was checked for error. Raw data from the survey comprises 285,186 observations in SUSENAS, 2011 and 285,400 observations in SUSENAS, 2014. However, due to the nature of the survey, there existed many missing values and zero values that had to be cleaned. Additionally, this study only prefers dataset for PLN consumers, so that observations from non-PLN consumers were dropped. Excluding such observations, 179,598 and 103,409 observations in the years 2011 and 2014, respectively, were included in the final analysis.

Electricity consumption data on SUSENAS used in this study only comes from PLN consumers and those who have a metering system in their houses indicated in the data. PLN is a national electricity wholesale company with extensive distribution and transmission line across Indonesia. Even though PLN is not the only company with a power plant, PLN is the sole electricity distributor in Indonesia. However, there are consumers, most of whom live outside Java and Bali islands and own a mini power generator in their houses in case of an emergency when a blackout occurs. Therefore, because electricity consumption in the SUSENAS data consists of electricity usage from all sources, consumption data from other power generation besides PLN has to be dropped.

Education data in SUSENAS are categorical data with 14 categories. It is because Indonesia has a national Islamic school and vocational school counted different from common school. Moreover, there exists a particular exam to gain a school certificate without actually going to school. However, following the common use of level of education variables in literature, this study re-groups some categories in raw data into one group to be regressed as the dummy variable.

\section{Result and Discussion}

The estimation results all have expected signs that mostly are statistically significant at $99 \%$ confidence level (see all detailed result in Appendix A). All estimated coefficients of the variable price in the natural logarithm that indicate the elasticity of price on electricity consumption has negative values. It means that increase in electricity price will decrease electricity consumption. At the same time, the change in income has a positive relationship with electricity consumption in all results.

The QR estimation results are illustrated in several X-Y graphs (Figures 1-5). Each graph illustrates the relationship between each independent variable shown on the Y-axis with the dependent variable and electricity consumption in the natural logarithm value, shown on the $\mathrm{X}$-axis. The horizontal dashed line in each graph represents the OLS regression result and their confidence interval, while the solid line and a gray area represent the QR result and confidence interval respectively. From such graphs, it is clear that QR can explain the dependent variable better than OLS regression since QR can capture varying effects of each independent variable across the distribution quantile of the dependent variable. 
Price elasticity appears to be inelastic in all $\mathrm{QR}$ results. It proves that electricity is a necessity good that cannot be substituted easily. Figures 1 and 2 illustrate the QR results for price elasticity across the conditional distribution of electricity demand in two groups of consumers given the two years' observation data.

Figure 1. QR result of the sensitivity of electricity demand to price in Low VA group

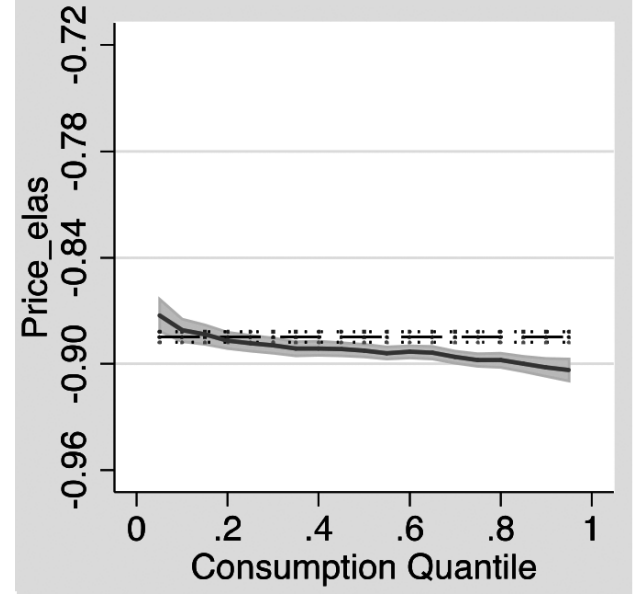

(a) 2011

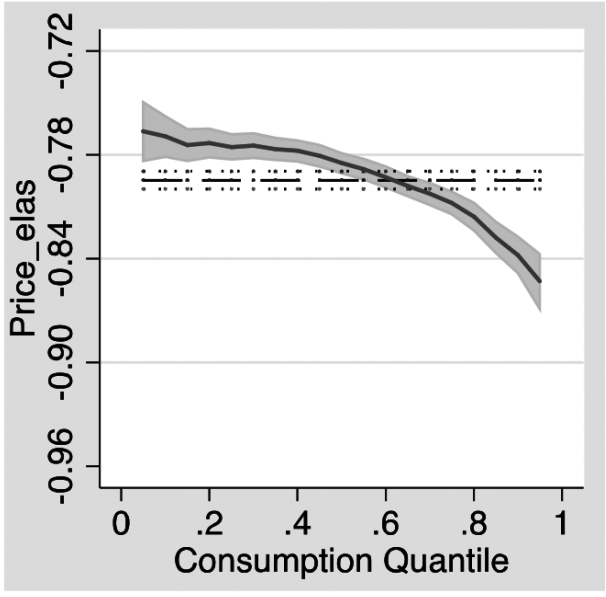

(b) 2014

Figure 1 presents the resulting profile of QR within the demand distribution in Low VA group. In both years, the price elasticity of the distribution of electricity consumption curves had a downward sloping trend line in negative value that varies within range (in absolute terms) from 0.87 to 0.90 in 2011 and from 0.77 to 0.85 in 2014 . The negative value indicates that consumption will decrease as price increases. The downward pattern of estimation result in Figure 1 illustrates that consumers in the higher quantile are more sensitive to change in price than consumers in the lower quantile.

It has to be noted that the responsiveness of electricity consumption to change in price in 2014 was lower than the responsiveness in 2011 in all percentiles of electricity consumption in the Low VA group. However, the magnitude of the decrease of elasticity was slightly different among the same quantile of consumption in a different year. Figure 1 shows that the 2014 trend line of QR result of the price elasticity across the distribution of electricity consumption is steeper than the trend line in 2011. Starting from the quantile value of 0.4 , the difference in the shape of such trend lines can be seen more clearly. It means that the lower to middle consumers' elasticity of price decreased more than the highest consumption level quantiles resulting in higher price sensitivity for middle to higher consumers than others in 2014. Such phenomenon may have occurred as people in the lower quantiles, lower-income people, for the most part, did not have the luxury of adjusting their consumption beyond their need unlike the middle to higher consumers. The middle to higher consumers is likely to own more electric appliances that may be adjusted flexibly with a change in price. 
Figure 2. QR of the sensitivity of electricity demand to price in High VA

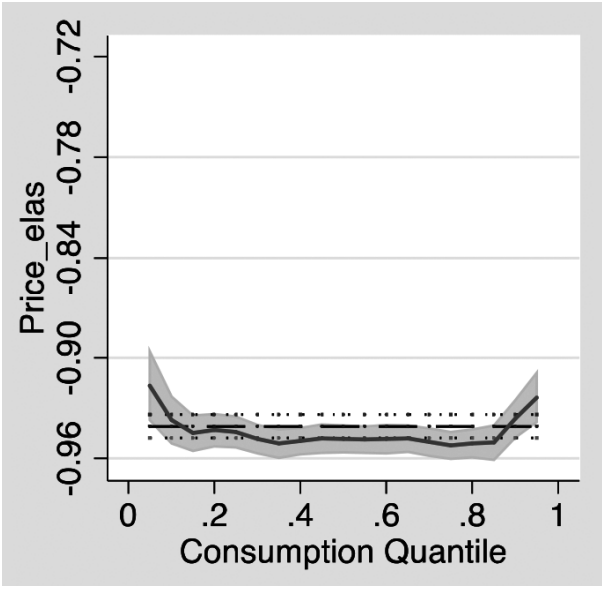

(a) 2011

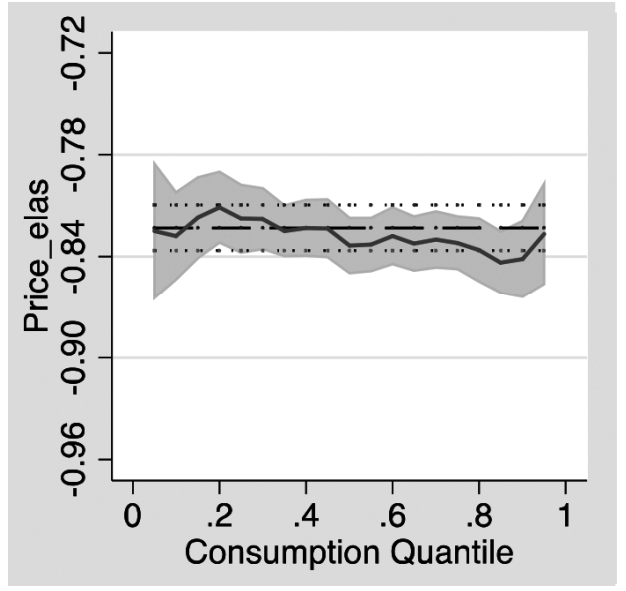

(b) 2014

Figure 2 presents the High VA group QR estimation results. The elasticity of price concerning quantiles' consumption in 2014 was smaller in roughly the same proportion than price elasticity across the quantiles in 2011. The estimated price elasticity for all quantiles' distribution of electricity demand is fairly the same for one year of observation. Price elasticity in both years was in the negative values that vary within range (in absolute terms) 0.92-0.95 in the year 2011 and $0.81-0.84$ in the year 2014 .

The relationship between price elasticity and electricity demand in 2011 as presented in Figure 2 (a) roughly looks like a U-shape pattern showing that consumers below the 20th percentile and in above 80th had higher elasticity than those in 20th-80th percentiles. The pattern supports the assumption that consumers in the lowest demand already consume electricity efficiently only for their necessities. Thus their price elasticity is low. Then, as demand goes up, the consumers become more responsive to the change in price. However, the highest percentile consumers probably have a high income so they can spend more on electricity without worrying about the price. In 2014, price elasticity decreased for all quantiles of demand with slight change in pattern from 2011 as illustrated in Figure 2 (b). There is a small inverted- $U$ shape in lower quantile of the 2014 consumption distribution profile different from 2011 relationship pattern between quantiles' consumption and price elasticity.

By looking at Figures 1 and 2 alone, the reason why price elasticity changed between 2011 and 2014 cannot be determined clearly. Thus, this study tried to run a similar regression for the years 2012 and 2013 with results as shown in Figure 3. Without the change in prices due to the regulation in 2013, the price elasticity of demand in all consumer groups had been fluctuating from 2011 until 2013. The price elasticity distribution along the quantile of consumers looked similar, the flat line for the Low VA group and U-shape for the High VA group. However, the distribution of price elasticity among the quantiles in 2014 was different as explained in previous paragraphs. Such condition might be attributed to the tariff regulation change in 2013 and 2014, including the Low VA consumer group whose price did not change. 
Figure 3. QR result of the sensitivity of electricity demand to price in the Low VA group in 2012 (a) and in 2013 (b), and in the High VA group in 2012 (c) and in 2013 (d)

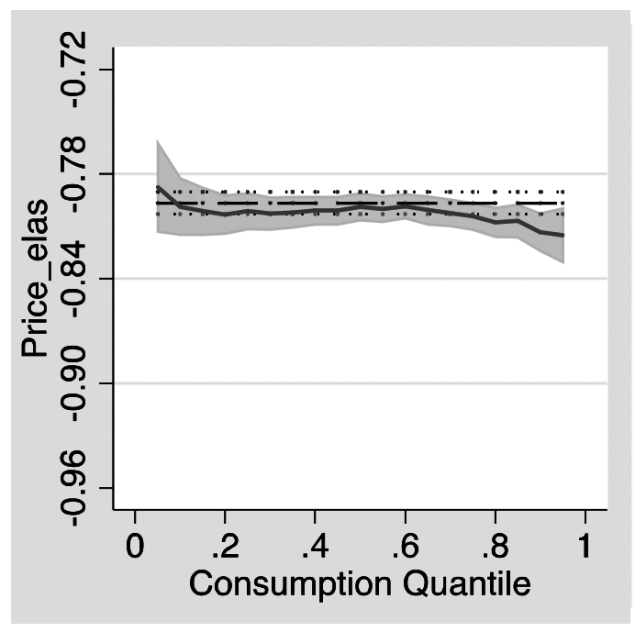

(a) Low VA, 2012

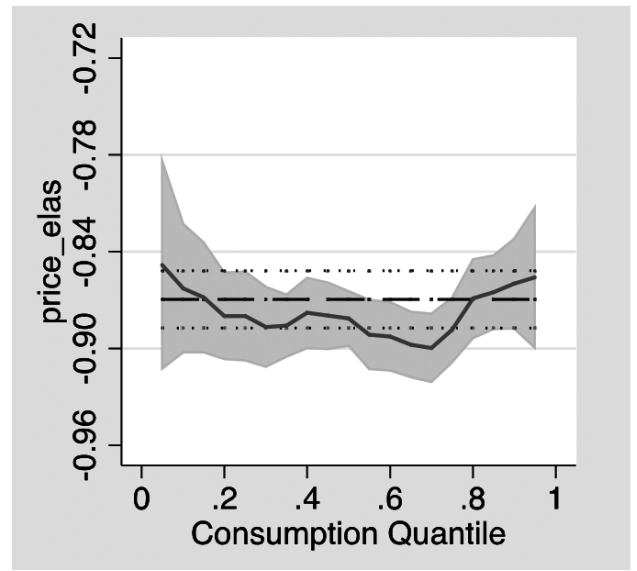

(c) High VA, 2012

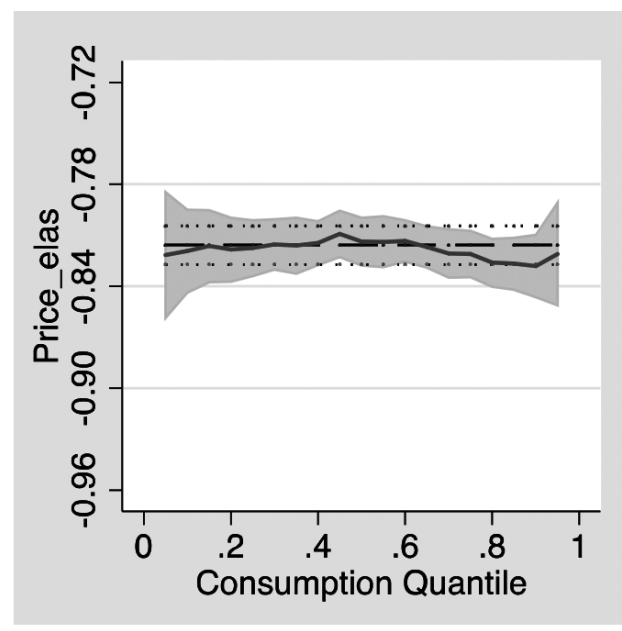

(b) Low VA, 2013

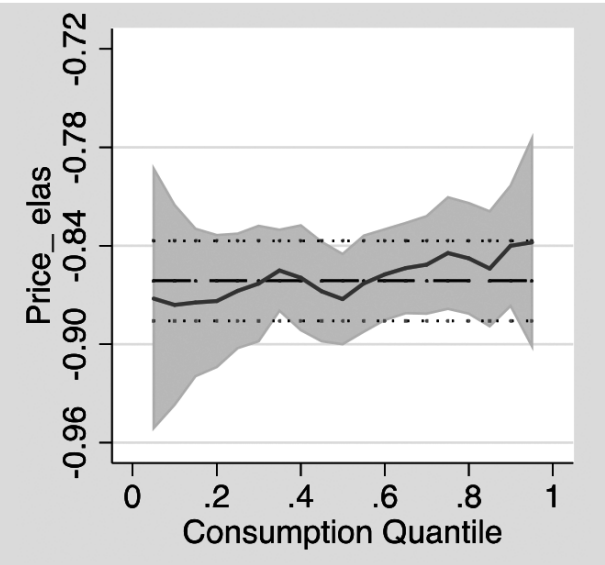

(d) High VA, 2013

The effect of the 2013-2014 electricity tariff change on the electricity demand in the Low VA group may have occurred indirectly through the inflation caused by the change in electricity regulation. The 2014 economic report on Indonesia published by Bank Indonesia (the Central Bank of Indonesia) in 2015 stated that the administered prices including energy prices significantly caused the 2014 inflationary pressure. The Bank of Indonesia suspected that the high value of inflationary pressure was due to the pricing reform of liquefied petroleum gas (LPG), gasoline and electricity. The change in electricity tariff itself had $0.64 \%$ share of the administered price inflation in 2014 (Bank Indonesia, 2015).

Looking at the results and comparing it with earlier studies, the basic profiles of the price elasticity of electricity consumption across the consumption distribution in Indonesia for the Low VA group are different with two previous studies conducted by Reiss and White in 2005 on the price elasticity of electricity demand in the US and a study by Romero-Jordan et al. in 2016 on the same subject in Spain. The price elasticity was increasing as the electricity consumption increasing. Simultaneously, for the High VA group, initially the shape was 
similar to the study of Romero-Jordan (2016) that is U shape, but the price elasticity profile became different after price changes.

It has to be noted that both in Indonesia and in the US have non-linear pricing schedule while in Spain the pricing mechanism is progressive pricing on the electricity consumption. Nevertheless, in the US, the price elasticity trend is increasing (Reiss and White, 2005). It proves that unlike in the US, in the Low VA group in Indonesia, if the quantile demand of electricity can reflect the quantile income, there is a positive relationship between household income and the consumption of electricity. The fact that the households in the Low VA group are people in the middle to low-income group suggests that even in the highest quantile of electricity demand, the consumers prone to price changes.

On the other hand, in the High VA group, the pricing mechanism is progressive pricing, even before the price changes. But, compared to the similar occurrence happened in Spain that is the prices changes, the price elasticity responded differently. This study found that the price elasticity in quantiles demand was collectively decreased after the price changes, while in Spain, the consumers in the middle quantiles of demand became more responsive to price changes. Romero-Jordan et al. (2016) argue that the middle quantiles demand consumers are the middle-income class that is most prone to the prices changes.

Figure 4. QR result of the sensitivity of electricity demand to income in the Low VA and High VA groups

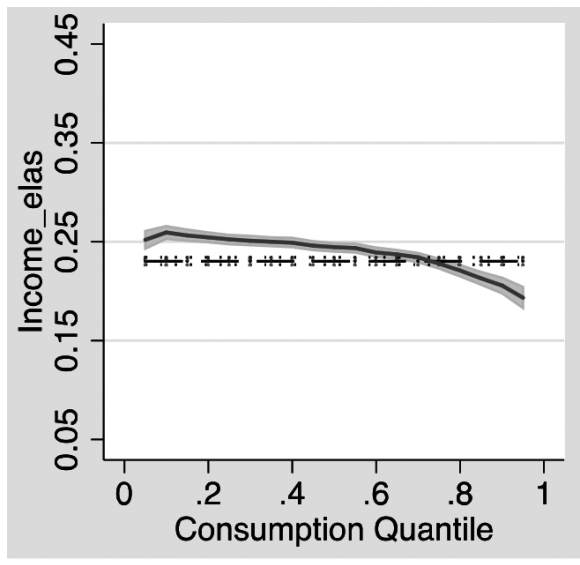

(a) Low VA, 2011

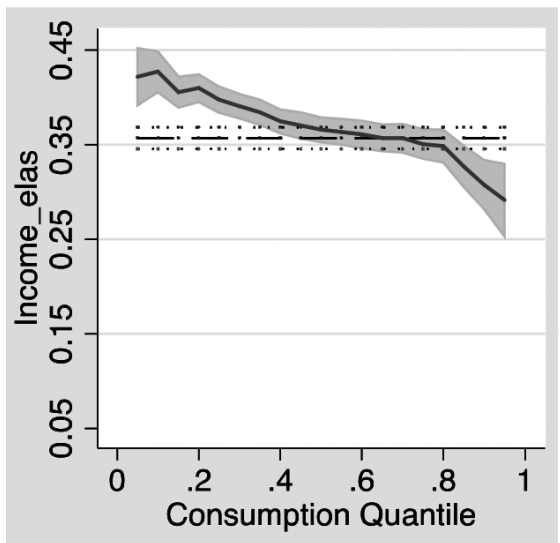

(c) High VA, 2011

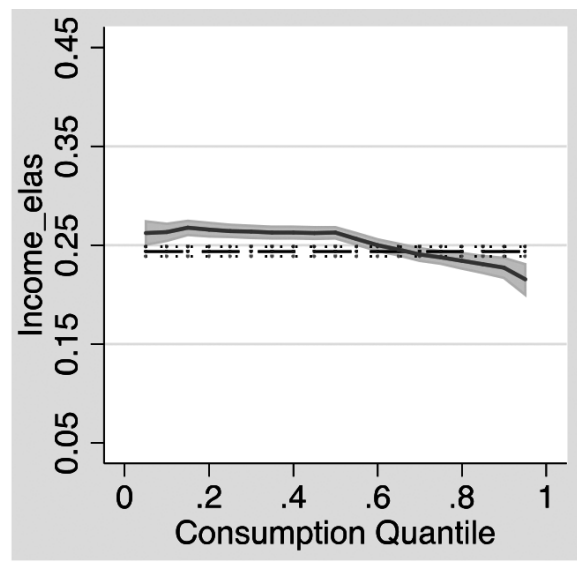

(b) Low VA, 2014

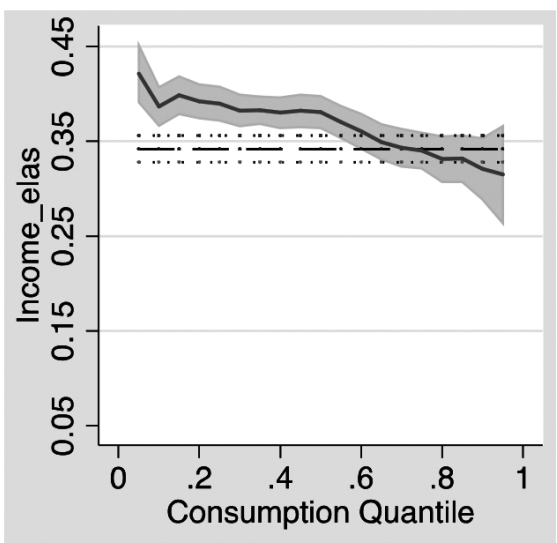

(d) High VA, 2014 
The investigation of the relationship between income elasticity and distribution of electricity consumption resulted in a similar shape for both consumer groups in both years (see Figure 4). The elasticity of income decreased throughout the quantiles of electricity consumption. Suppose that the conditional distribution of electricity consumption represents the income level of the households, the poorest household is in the lowest quantile of electricity demand and the richest is in the highest quantile. The estimated results suggest that poor households will increase their electricity consumption more than rich households when they have an increase in income. Thus, as the households become richer, the effect of a rise in income to electricity demand becomes smaller.

Overall, the income elasticity of High VA group was higher than the income elasticity of Low VA group. Additionally, the gap between the lowest and the highest quantiles' distribution of consumption was more significant in High VA group than in Low VA group. The values of income elasticity in the Low VA group were positive within the range 0.26-0.19 in the year 2011 and $0.27-0.22$ in the year 2014. At the same time, the estimated income elasticity in the High VA group was within the range $0.43-0.29$ in 2011 and $0.42-0.32$ in 2014.

Figure 5. QR result of the sensitivity of electricity demand to income in the Low VA group in 2012 (a) and in 2013 (b), and in the High VA group in 2012 (c) and in 2013 (d)

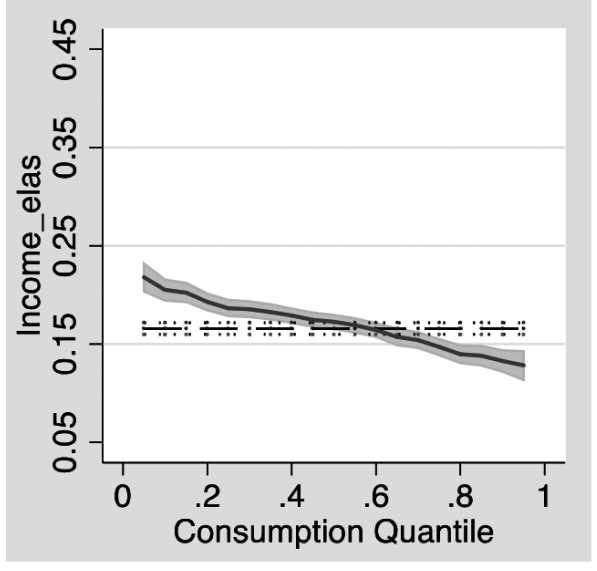

(a) Low VA, 2012

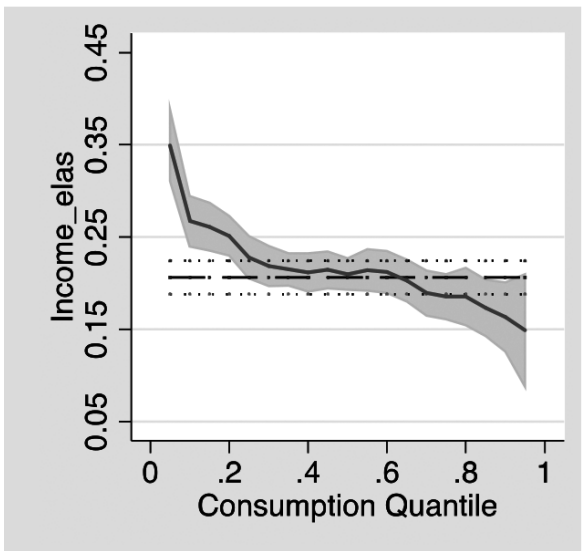

(c) High VA, 2012

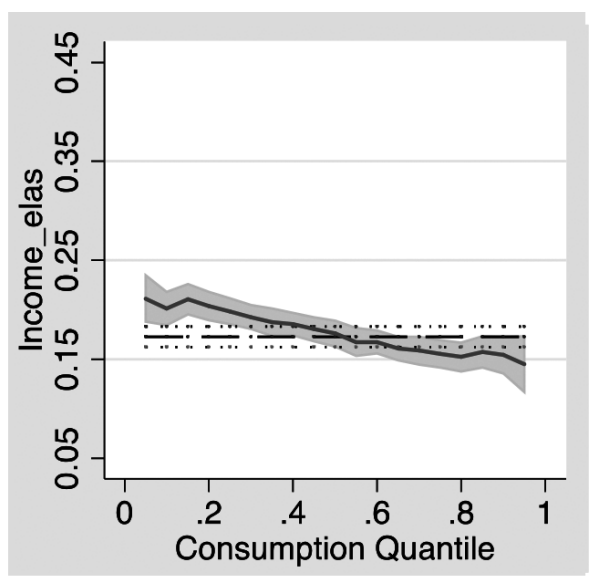

(b) Low VA, 2013

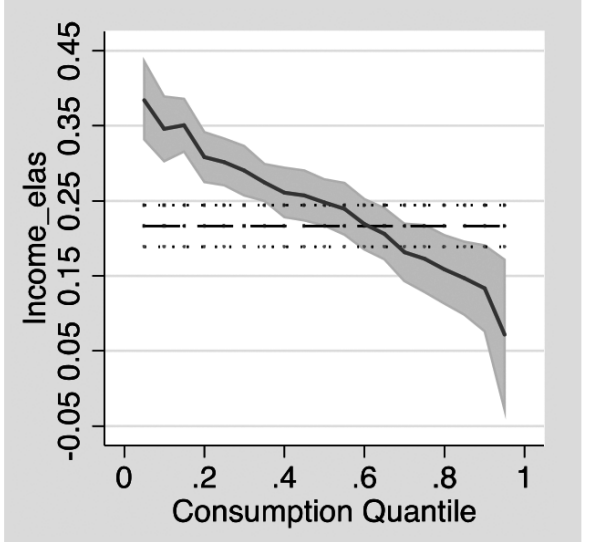

(d) High VA, 2013 
It is understandable that income elasticity of High VA group is higher than Low VA group and the gap of income elasticity among all quantiles in High VA group is broader than those in the Low VA group. It may be because the consumers with the higher power capacity of electricity are likely to have the higher income than their counterparts. As a result, the consumers in High VA group are more responsive to change in income; because they may tend to use more electric appliances than people in Low VA group. Another finding is that the QR result line of both groups in 2014 looks moderately flatter than in 2011. It implies that the responsiveness of the change in income became equal between the quantiles of consumption in 2014 than in 2011. However, the change in values on each quantile is very small.

Nevertheless, findings on the income elasticity of demand above are incomplete without knowing the condition in 2012 and 2013. Figure 5 shows that average income elasticity in 2012 and 2013 was lower than in 2011 and 2014. The decreasing income elasticity may be due to an increase in income per capita throughout the years as reported by Bank Indonesia (Central Bank of Indonesia) in 2014's economic report of Indonesia (2015). As income increases, the proportion of income for electricity as a necessity good, most likely decreases. However, in 2014, income elasticity increased to the 2011 level in both observed groups, even though the income per capita in 2014 was higher than in 2013.

There are two possibilities regarding why the income elasticity in 2014 became similar to that in 2011. First, this indicates that change in the price of electricity in 2013 neutralized the effect of the increasing income of households during 2011-2013. Therefore, when the price of electricity and income increased at the same time in 2014, the income elasticity of electricity demand seemed unchanged from income elasticity in 2011. However, there is another possible reason. In 2014, private consumption expenditure decreased as the economy decelerated (Bank Indonesia, 2015). It can be assumed that the proportion of real income to spend on electricity consumption became higher than before. Therefore, the income elasticity of demand increased. Additionally, general election held in 2014 might have contributed to the economy.

With regards to earlier studies, this research finds that income elasticity of electricity demand in Indonesia is slightly higher than in OECD countries including Spain with the values below 0.2 (Krishnamurthy and Kriström, 2015; Romero-Jordan et al., 2016). This result may suggest that household income in Indonesia compared to OECD countries have the more important role in consideration for electricity consumption.

Besides price elasticity and income elasticity, this study also examined some characteristics of households that factored the decision of electricity consumption. The suspected factors were years of education of the head of the family, ownership of equipment, and location of households whether in Java and Bali Islands and whether the house was an urban area.

From all such factors, the results of years of education have the most not statistically significant coefficient estimation result mostly found in the High VA group consumers (see 
Appendix A, Table 3 and 4). The estimation results for such household group imply that levels of education of the breadwinner had no impact on electricity consumption in 2011. However, in 2014, when the breadwinner had more than 12 years of education, the impact of their education was significant at $29.8 \%$ in 0.05 quantile consumption and then decreased for the remaining quantiles.

On the other hand, the levels of education have a positive impact on electricity consumption in the Low VA group in both given years (See Appendix, Table 1 and 2). The longer the education the breadwinner received, the higher the possibility of deciding to consume more electricity. Nevertheless, the impact was also decreasing along with the increase of consumption quantiles.

The estimated coefficients for two dummy location variables used-javabali and urban—are statistically significant (see Appendix). The first dummy variable_-javabali_has statistically significant negative value coefficients; meaning that when households live on Java or Bali Islands, electricity consumption will decrease more than when they live on other islands. However, the estimated values are very small at around -0.1 or even less, which may indicate that living location inside or outside Java and Bali Islands has little impact on the consumption behavior. On the other hand, the second dummy variable-urbanhas statistically significant positive value coefficients. Therefore, based on the estimation result in Appendix, people in the urban area have a positive relationship with electricity consumption than people in rural area. Nevertheless, the magnitude of the impact is small between $0.2-0.3$.

The last dummy variable used in this study is equipment that reflects the ownership of electrical appliances. The results in Appendix also show the impact of ownership of air conditioner, refrigerator, and water heater on electricity consumption that decreases as the quantile of consumption increases. The value of the impact is higher in the group of consumers in High VA group than in the Low VA group. Such condition may happen because of the limitation that maximum power, which can be used by the former, is higher than that of the latter.

There are some highlights of the findings. Firstly, the government regulation to raise the electricity prices for specific groups may also affect other groups. Based on the estimation results, even though the High VA was the only target of the government pricing regulation in the residential sector, the elasticity of price in the Low VA group also decreased in 2014 with different proportion. The movement of the Low VA might have happened because of the change in other prices, besides electricity price during the years. However, it can also be caused by the indirect effect of changes in price in the High VA group or changes in commercial and industrial sector electricity prices. On the other hand, the impact of the change in pricing regulation on the income elasticity of electricity demand remains unclear. An additional investigation to find income elasticity between 2011 and 2014 found lower results than the 2011 or 2014 values. Such results may have been caused by the change in the price of the High VA group in 2013-2014 that negated the effects of increasing income throughout 2011-2013 or because the economy slowed down in 2014. 
The findings in this study also suggest that income elasticity of electricity demand in Indonesia may be influenced by the change in the economy and pricing regulation. Hence, the effect of the change in pricing regulation alone on income elasticity in future is unclear. Therefore, it is vital for the government to maintain economic stability. So that changes in price may have a little impact on income elasticity

\section{Conclusion}

This paper investigated price and income elasticity concerning electricity consumption in 2 different groups (Low VA and High VA) in 2 different years. The estimated price elasticity of demand shows that electricity is inelastic in negative values. At the same time, the estimation of income elasticity of demand presents the positive value. The absolute values of both estimated elasticity indicate that consumption of electricity is more responsive to change in price than to change in income. Additionally, the values for price and income elasticity are estimated to be higher in the High VA group than the values in the Low VA group.

From such findings, there are some policy implications. First, the government has to be careful in proposing changes in electricity price for a specific group of households, because the effect of price change on the price elasticity of demand may not only be felt by the exposed group but also the remaining household groups. Second, the government may also pursue more policy towards efficiency of energy including regulation to push more efficient electric equipment in the domestic market. Aside from environmental issue, energy efficiency can make consumers less responsive to the electricity price changes.

Some limitations of this study may provide fruitful avenues for future research. First, due to the limitation of data availability, this research used the cross section data only in two points of years such as 2011 and 2014, which intended to capture the electricity demand behavior before and after the price changes. Therefore, the complete view of the change in price and income elasticity throughout the conditional distribution of electricity consumption may not have been achieved. It may be more beneficial to use panel data covering some years before and after the price changes. Another limitation of this study is that consumers' welfare condition was not observed. As a suggestion, future research can investigate the change in welfare due to price changes. With the addition of welfare analysis, the impact of policy change on electricity prices will become more comprehensive.

\section{References}

Alberini, A., \& Filippini, M. (2011). Response of Residential Electricity Demand to Price: The Effect of Measurement Error. Energy Economics. Vol. 33(5): 889-895. doi: https:// doi.org/10.1016/j.eneco.2011.03.009.

Alberini, A., Gans, W., \& Velez-Lopez, D. (2011). Residential Consumption of Gas and Electricity in The U.S.: The Role of Prices and Income. Energy Economics. Vol. 33(5): 870-881. doi: https://doi.org/10.1016/j.eneco.2011.01.015. 
Batih, H., \& Sorapipatana, C. (2016). Characteristics of Urban Households' Electrical Energy Consumption in Indonesia and Its Saving Potentials. Renewable and Sustainable Energy Reviews. Vol. 57: 1160-1173. doi: https://doi.org/10.1016/j. rser.2015.12.132.

Damuri, Y. R. (2013). Pricing Practices in Indonesia's Electricity Power Services. Retrieved from https://apindo.or.id/userfiles/publikasi/pdf/Pricing_Practices_in_Electricity_ Services_-_Indonesia.pdf.

Durand-lasserve, O., Campagnolo, L., Chateau, J., \& Dellink, R. (2015). Modelling of Distributional Impacts of Enery Subsidy Reforms: An Illustration with Indonesia. OECD Environment Working Papers, No. 86. Paris: OECD Publishing. doi: https:// doi.org/10.1787/5js4k0scrqq5-en.

Hagfors, L. I., Bunn, D., Kristoffersen, E., Staver, T. T., \& Westgaard, S. (2016). Modeling The UK Electricity Price Distributions Using Quantile Regression. Energy. Vol. 102: 231-243. doi: https://doi.org/10.1016/j.energy.2016.02.025

Huang, W. H. (2014). The Determinants of Household Electricity Consumption in Taiwan: Evidence From Quantile Regression. Energy. Vol. 87: 120-133. doi: https://doi. org/10.1016/j.energy.2015.04.101

Krishnamurthy, C. K. B., \& Kriström, B. (2015). A Cross-country Analysis of Residential Electricity Demand in 11 OECD Countries. Resource and Energy Economics. Vol. 39: 68-88. doi: https://doi.org/10.1016/j.reseneeco.2014.12.002

Longhi, S. (2015). Residential Energy Expenditures and The Relevance of Changes in Household Circumstances. Energy Economics. Vol. 49: 440-450. doi: https://doi. org/10.1016/j.eneco.2015.03.018.

Narayan, P. K., \& Smyth, R. (2005). The Residential Demand for Electricity in Australia: An Application of The Bounds Testing Approach to Cointegration. Energy Policy. Vol. 33(4): 467-474. doi: https://doi.org/10.1016/j.enpol.2003.08.011

Nesbakken, R. (1999). Price Sensitivity of Residential Energy Consumption in Norway. Energy Economics. Vol. 21(6): 493-515. doi: https://doi.org/10.1016/S01409883(99)00022-5

Pourazarm, E., \& Cooray, A. (2013). Estimating and Forecasting Residential Electricity Demand in Iran. Economic Modelling. Vol. 35: 546-558. doi: https://doi.org/10.1016/j. econmod.2013.08.006

Reiss, P. C., \& White, M. W. (2005). Household Electricity Demand, Revisited Household Electricity Demand, Revisited. Review of Economic Studies. Vol. 72: 853-883. doi: https://doi.org/10.1111/0034-6527.00354

Romero-Jordan, D., del Rio, P., \& Penasco, C. (2016). An Analysis of The Welfare and Distributive Implications of Factors Influencing Household Electricity Consumption Energy Policy. Vol. 88: 361-370. doi: https://doi.org/10.1016/j. enpol.2015.09.037. 
Yamasaki, E., \& Tominaga, N. (1997). Evolution of An Aging Society and Effect on Residential Energy Demand. Energy Policy. Vol. 25(11): 903-912. doi: https://doi. org/10.1016/S0301-4215(97)00040-2 


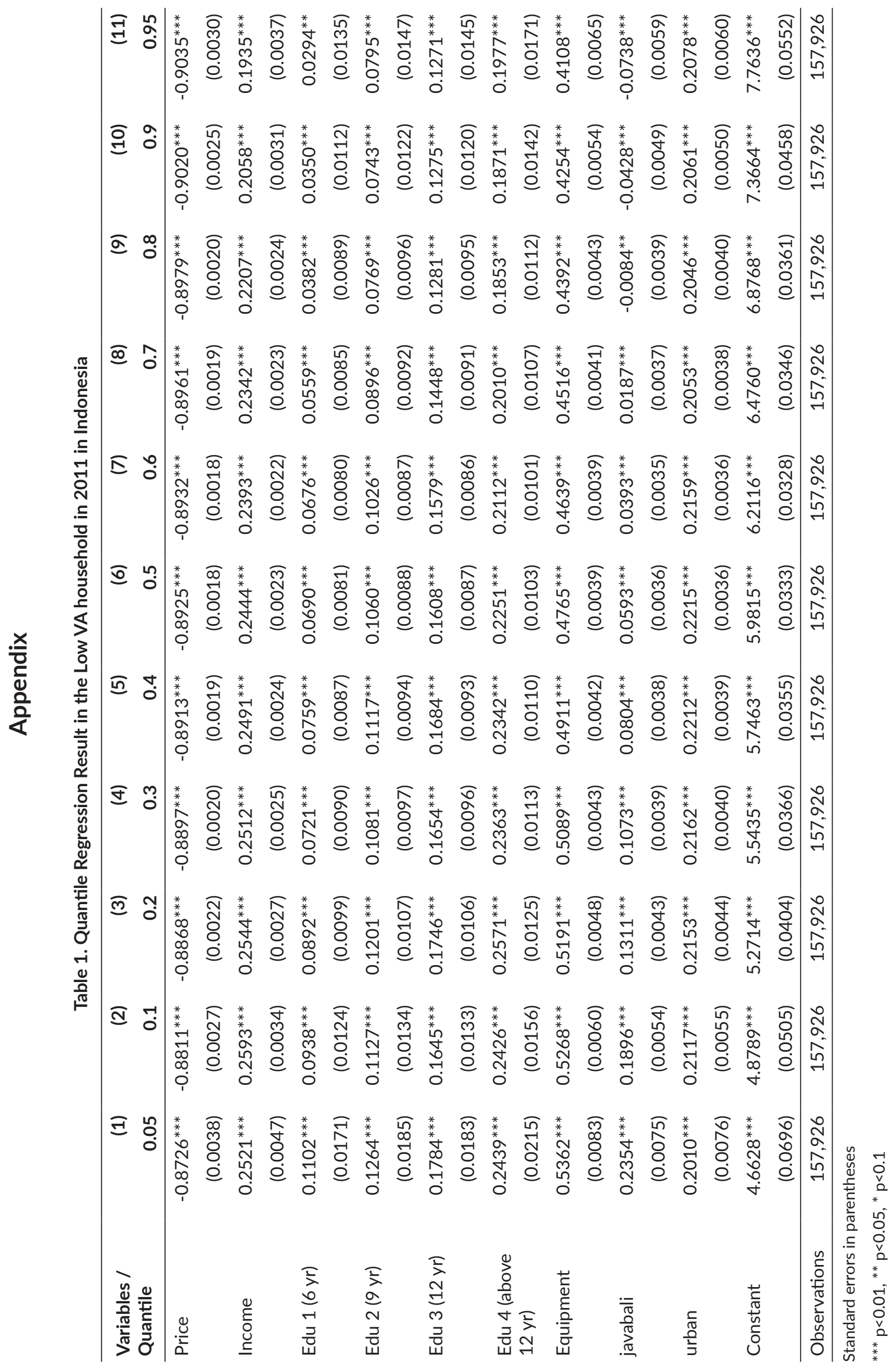




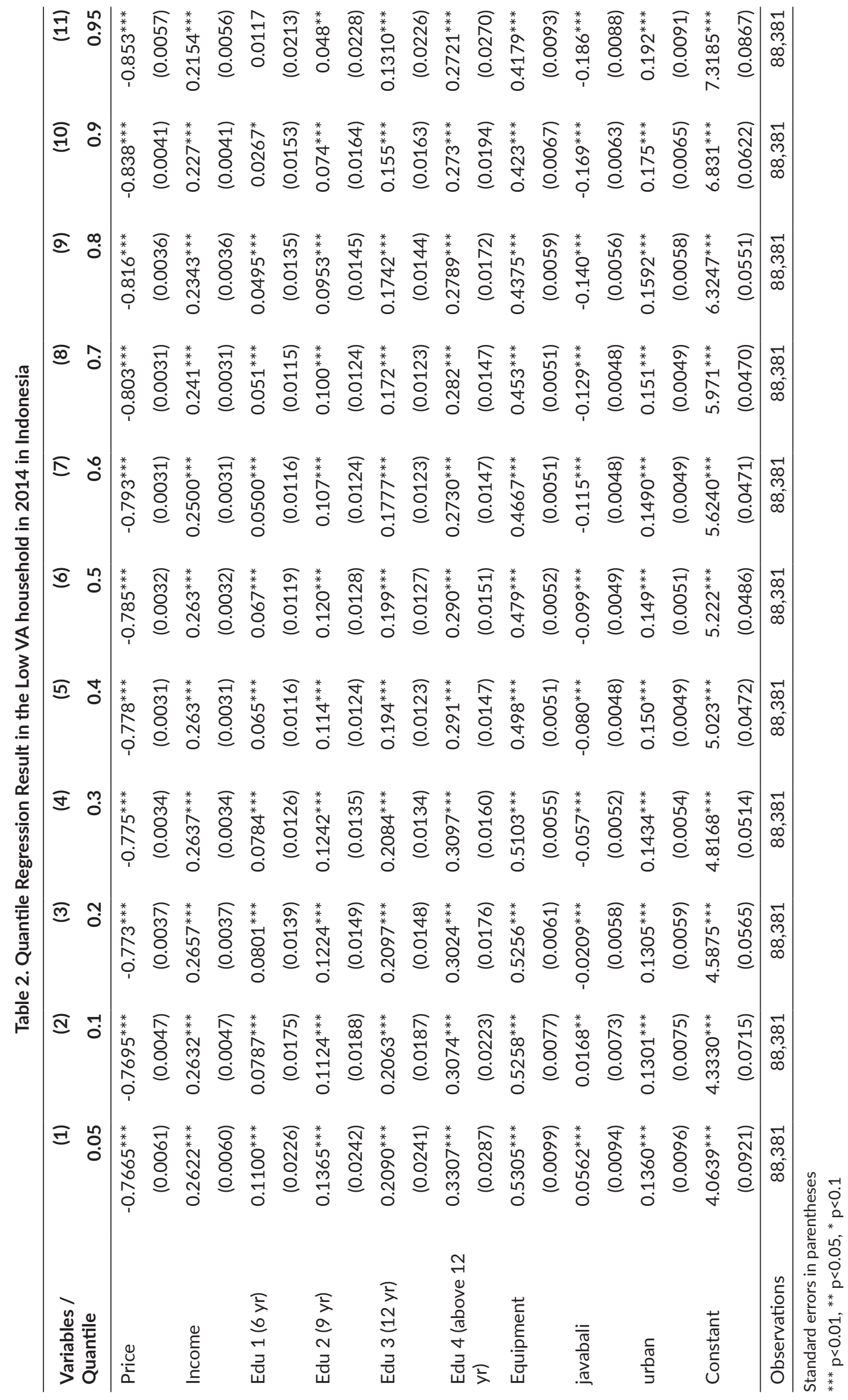




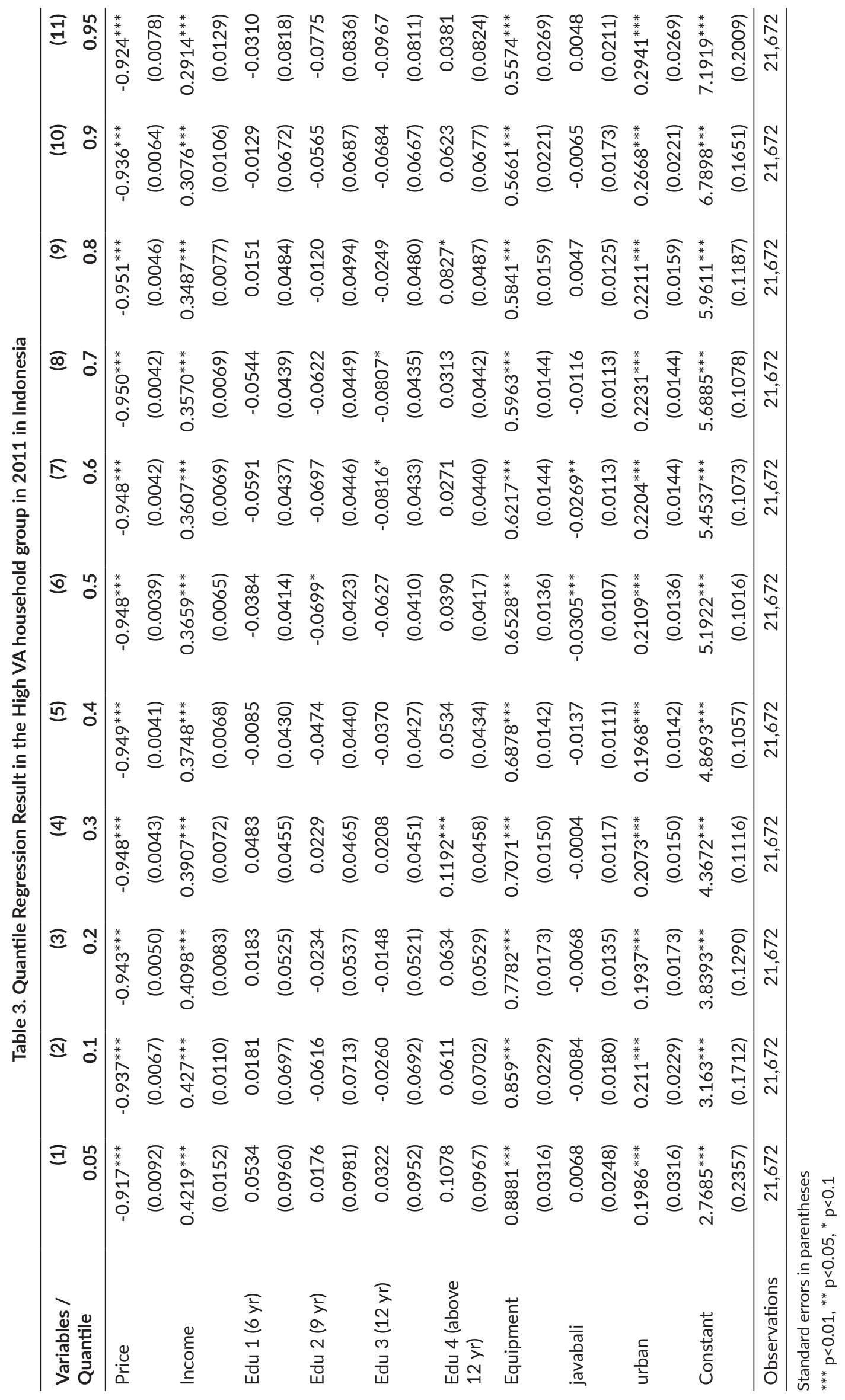




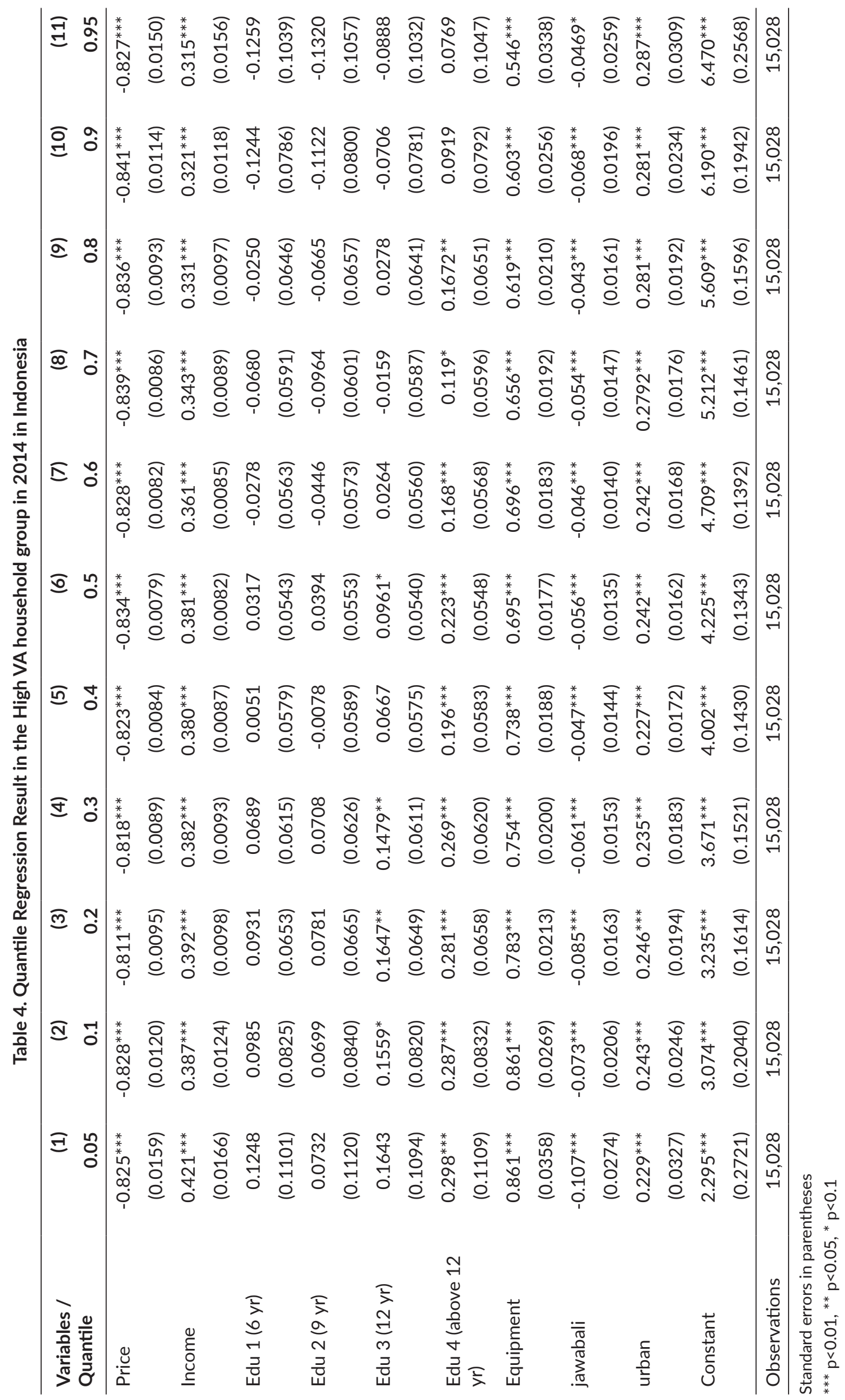

